
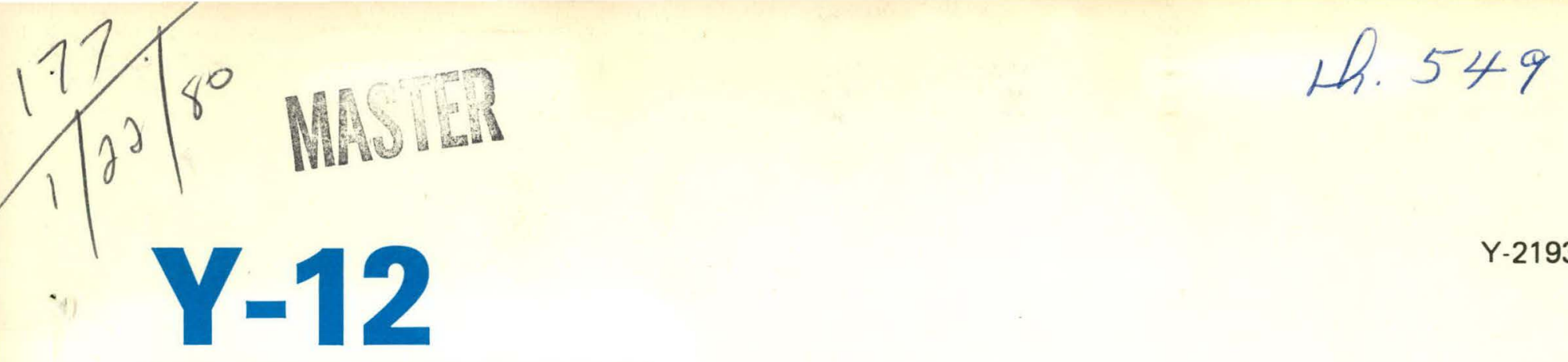

OAK

RIDGE

Y-12

PLANT

DETERMINATION OF NITROGEN AND OXYGEN IN URANIUM METAL BY INERT-GAS FUSION

\section{UNION \\ CARBIDE}

W. F. Carden

December 1979 


\section{DISCLAIMER}

This report was prepared as an account of work sponsored by an agency of the United States Government. Neither the United States Government nor any agency Thereof, nor any of their employees, makes any warranty, express or implied, or assumes any legal liability or responsibility for the accuracy, completeness, or usefulness of any information, apparatus, product, or process disclosed, or represents that its use would not infringe privately owned rights. Reference herein to any specific commercial product, process, or service by trade name, trademark, manufacturer, or otherwise does not necessarily constitute or imply its endorsement, recommendation, or favoring by the United States Government or any agency thereof. The views and opinions of authors expressed herein do not necessarily state or reflect those of the United States Government or any agency thereof. 


\section{DISCLAIMER}

Portions of this document may be illegible in electronic image products. Images are produced from the best available original document. 
Reference to a company or product name does not imply approval or recommendation of the product by Union Carbide Corporation or the Department of Energy to the exclusion of others that may meet specifications.

Printed in the United States of America. Available from National Technical Information Service

U.S. Department of Commerce

5285 Port Royal Road, Springfield, Virginia 22161

Price: Printed Copy A02; Microfiche A01

This report was prepared as an account of work sponsored by an agency of the United States Government. Neither the United States Government nor any agency thereof, nor any of their employees, nor any of their contractors, subcontractors, or their employees, makes any warranty, express or implied, nor assumes any legal liability or responsibility for any third party's use or the results of such use of any information, apparatus, product or process disclosed in this report, nor represents that its use by such third party would not infringe privately owned rights. 


\title{
DETERMINATION OF NITROGEN AND OXYGEN IN URANIUM METAL BY INERT-GAS FUSION
}

\author{
W. F. Carden
}

Plant Laboratory Department

Y-12 Product Certification Division

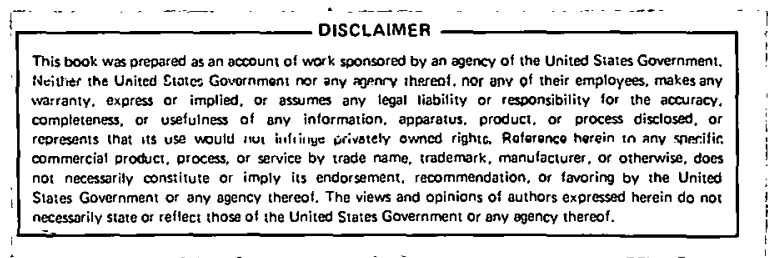

Oak Ridge Y-12 Plant

P. O. Box Y, Oak Ridge, Tennessee 37830

Prepared for the Department of Energy Under US Government Contract W-7405-eng-26 


\begin{abstract}
An improved analytical method has been developed using inert-gas fusion for determining the nitrogen and the oxygen contents of uranium metal. The analytical method is applicable to concentrations of nitrogen and oxygen ranging from 1 microgram per gram to 1000 micrograms per gram for each gas. In uranium metal, the limit of error for a single determination at the $95 \%$-confidence level, at the 12-micrograms-per-gram-nitrogen level, is \pm 3 micrograms per gram nitrogen and, at the 20 -micrograms-per-gram-oxygen level, is \pm 3 micrograms per gram oxygen. Nitrogen and oxygen concentrations are determined by using a nitrogen-oxygen determinator.
\end{abstract}


CONTENTS

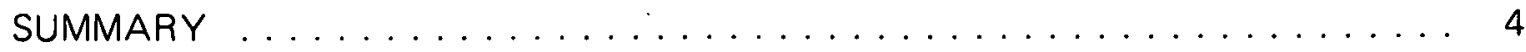

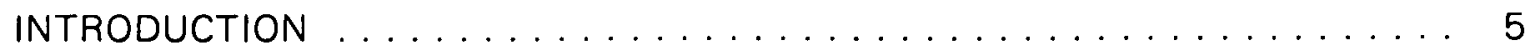

RESOLUTION OF NITROGEN AND OXYGEN IN URANIUM METAL . . . . . 6

General Procedure . . . . . . . . . . . . . . . . . . . . . 6

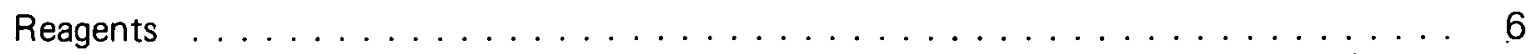

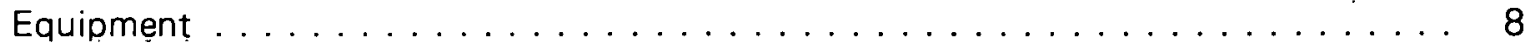

Functions and Preparation of Equipment $\ldots \ldots \ldots \ldots \ldots \ldots \ldots \ldots \ldots$

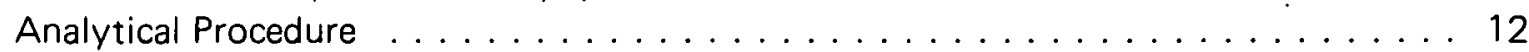

Results .............................. 14

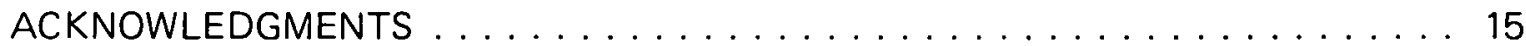




\section{SUMMARY}

Improvements have been made in the determination of nitrogen and oxygen in uranium metal by using a Leco TC30 Nitrogen-Oxygen Determinator. (a)

The single-use graphite crucible along with a platinum cup used to enclose the uranium-metal sample have greatly improved the precision and accuracy of the component results. This method eliminates the bias problem of low-nitrogen results which occasionally occurs with fusion methods when using a platinum bath.

In uranium metal, the limit of error for a single determination of nitrogen at the $95 \%$-confidence level at the $12-\mu \mathrm{g} / \mathrm{g}$-nitrogen level is $\pm 3 \mu \mathrm{g} / \mathrm{g}$ nitrogen. The limit of error for a single determination of oxygen at the $95 \%$-confidence level at the $20-\mu \mathrm{g} / \mathrm{g}$-oxygen level is $\pm 3 \mu \mathrm{g} / \mathrm{g}$ oxygen.

(a) Instruction Manual, TC30 Nitrogen-Oxygen Determinator Model 760-200; Leco Corporation, St Joseph, Michigan (1974). 


\section{INTRODUCTION}

Nitrogen and oxygen contents in uranium metal are determined with a fast and accurate analytical method using an inert-gas-fusion technique in the Oak Ridge $Y-12$ Plant $(b)$ Laboratory.

Previous methods, using a vacuum-fusion technique, required up to one hour for the determination of the nitrogen and the oxygen in one aliquant. Other methods using a platinum bath at approximately $2000^{\circ} \mathrm{C}$ are not always accurate; and frequently, low-biased-nitrogen results were obtained. Using a new instrument with an inert-gas-fusion technique and a single-use graphite crucible holding the sample in a platinum cup, the nitrogen and oxygen in a uranium-metal sample are determined in approximately four minutes.

(b) Operated by the Union Carbide Corporation's Nuclear Division for the Department of Energy. 


\section{RESOLUTION OF NITROGEN AND OXYGEN IN URANIUM METAL}

\section{GENERAL PROCEDURE}

The nitrogen and the oxygen contents of uranium metal are determined by using a Leco Model TC30 Nitrogen-Oxygen Determinator. The instrument (Figure 1) utilizes an inert-gas-fusion technique whereby the sample (enclosed in a platinum cup within a single-use graphite crucible) is fused in a helium atmosphere to release hydrogen, nitrogen, and oxygen as carbon monoxide (CO). The released gases pass through a tube of heated copper oxide ( $\mathrm{CuO}$ ), which oxidizes the $\mathrm{CO}$ to carbon dioxide $\left(\mathrm{CO}_{2}\right)$ and the hydrogen to water. The remaining gases pass into magnesium perchlorate $\left.\left[\mathrm{Mg}_{(\mathrm{ClO}}\right)_{2}\right]$ where water is absorbed and removed from the nitrogen and $\mathrm{CO}_{2}$ that remained in the carrier gas and are separated in a chromatographic column. The nitrogen and $\mathrm{CO}_{2}$ are measured with thermistor bridge, and the bridge output is calibrated to display parts per million of nitrogen and oxygen.

The limit of error for a single determination of nitrogen in uranium metal at the $95 \%$-confidence level at the $12-\mu \mathrm{g} / \mathrm{g}$-nitrogen level is $\pm 3 \mu \mathrm{g} / \mathrm{g}$. The limit of error for a single determination of oxygen in uranium metal at the $95 \%$-confidence level at the $20-\mu \mathrm{g} / \mathrm{g}$-oxygen level is $\pm 3 \mu \mathrm{g} / \mathrm{g}$ oxygen.

\section{REAGENTS}

The following reagents are required in this general procedure:

Acetone (reagent grade)

Ascarite $^{(\mathrm{c})}$ [sodium hydroxide $(\mathrm{NaOH})$ on asbestos]

Copper oxide (reagent grade)

Grease (silicone)

Helium (high purity, 99.9997\% pure)

Magnesium perchlorate (reagent grade)

Standards (nitrogen and oxygen)

\begin{tabular}{|c|c|c|}
\hline Leco Numbers & $\begin{array}{c}\text { Nitrogen } \\
\mu \mathrm{g} / \mathrm{g}\end{array}$ & $\begin{array}{c}\text { Oxygen } \\
\mu \mathrm{g} / \mathrm{g}\end{array}$ \\
\hline $501-660$ & 11 & 50 \\
\hline $501-661$ & 384 & 68 \\
\hline $501-551$ & 44 & - \\
\hline $501-552$ & 109 & $-\cdots$ \\
\hline
\end{tabular}

(c) Arthur H. Thomas Company, Philadelphia, Pennsylvania. 


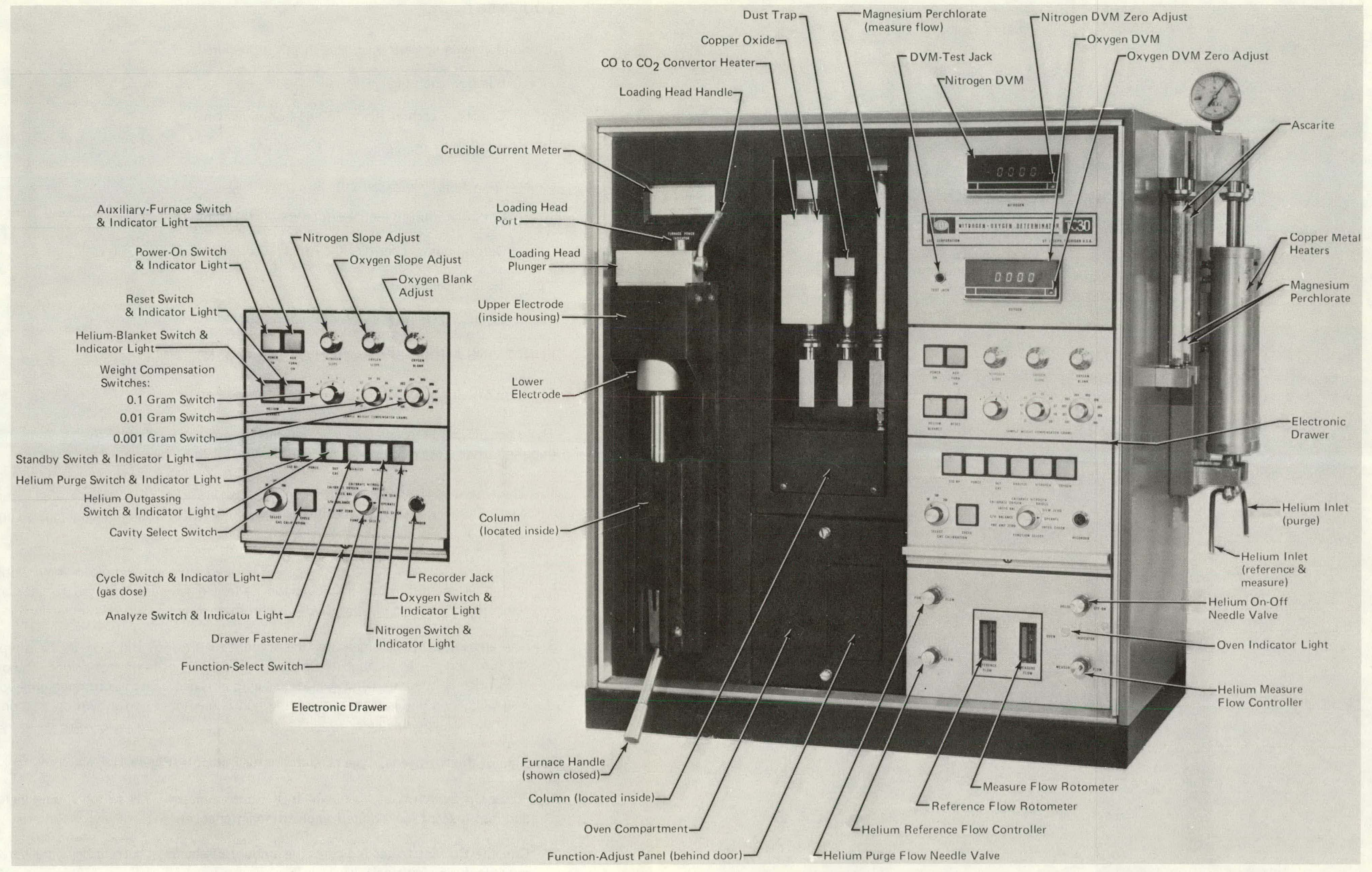

Figure 1. LECO TC3O NITROGEN-OXYGEN DETERMINATOR. 


\section{EQUIPMENT}

The following equipment is utilized in this procedure:

Balance, analytical

Crucibles, carbon (Leco $760-414$ or equivalent)

Files, taper (6-inch length)

mill (10-inch length)

Foil, platinum (6-inch $\times 6$-inch sheet, 1 -mil thick)

Determinator, Leco TC30 Nitrogen-Oxygen, Model 760-200

Tissues, cleansing

Tweezers, stainless steel with platinum tips

\section{FUNCTIONS AND PREPARATION OF EQUIPMENT}

\section{Function of Nitrogen-Oxygen Determinator Components}

The Leco TC30 Nitrogen-Oxygen Determinator consists of three basic components; the impulse furnace, the reagent system, and the analytical system.

1. The impulse furnace elevates the temperature of the sample and crucible to approximately $2700^{\circ} \mathrm{C}$. The furnace is connected to a sample-loading head and to the analytical section through the reagent system.

2. The reagent system transfers the gases liberated from the sample in the crucible to the analytical section (after oxidizing the hydrogen to water and $\mathrm{CO}$ to $\mathrm{CO}_{2}$ and after separating the nitrogen from $\mathrm{CO}_{2}$ in a chromatographic column).

3. The analytical system measures the amount of nitrogen and $\mathrm{CO}_{2}$ in the sample when the nitrogen passes through the measuring cell of the thermistor bridge. The output of the bridge is integrated and is shown as $\mu \mathrm{g} / \mathrm{g}$ nitrogen on an electronic digital voltmeter. The $\mathrm{CO}_{2}$ then elutes from the column and is measured and shown on a second digital voltmeter as $\mu \mathrm{g} / \mathrm{g}$ oxygen.

\section{Function of the Nitrogen-Oxygen Determinator Controls (Figure 1)}

1. Power-On Switch controls power to the determinator. This switch should be left on at all times (except for required electrical maintenance).

2. Crucible Current Meter indicates the amount of electrical current being delivered to the crucible during ignition. 
3. Auxiliary-Furnace Switch controls electrical power to the auxiliary furnace $\left(\mathrm{CO}+\mathrm{CO}_{2}\right.$ converter heater).

4. Nitrogen Digital-Voltmeter Switch controls electrical power to the nitrogen digital voltmeter.

5. Oxygen Digital-Voltmeter Switch controls electrical power to the oxygen digital voltmeter.

6. Standby Switch controls electrical power to deenergize solenoids for shutdown procedure.

7. Purge Switch controls helium purge of the TC30 during sample and crucible loading.

8. Outgas Switch controls helium outgas of the TC30 after sample and crucible loading; controls furnace outgassing of crucible.

9. Analyze Switch controls electrical power used to heat crucible and sample in furnace.

10. Nitrogen Switch controls electrical power used to integrate total nitrogen and to record on nitrogen digital voltmeter.

11. Oxygen Switch controls electrical power used to integrate total oxygen and to record on oxygen digital voltmeter.

12. Oven Indicator Light indicates electrical current is energizing the oven heater.

13. Function-Select Switch selects the proper mode, operational or checkout.

14. Function-Adjust Panel is the electronic-function checkout panel for adjustments by electronics maintenance personnel.

15. Digital-Voltmeter-Test Jack is for function-adjust panel for electronic checkout.

16. Helium On-Off Needle Valve controls the flow of helium to determinator.

17. Helium. Purge-Flow Needle Valve controls the helium flow to the purge system.

18. Helium Measure-Flow Controller controls helium flow to the Measure Flow Rotometer (approximate reading of 210 ).

19. Helium Reference-Flow Controller controls helium flow to the Reference Flow Rotometer (approximate reading of 50 ).

20. Helium Control Regulators (mounted on adjacent wall panel) control the helium flow to the instrument and adjust each regulator to 40-psi pressure. 
21. Helium-Blanket Indicator Switch controls helium flow to the sample after the crucible has been outgassed.

22. Reset Switch controls outgassing cycle without heating the crucible.

\section{Preparation of Nitrogen-Oxygen Determinator Equipment}

1. Coolant Circulator. Check water supply to the coolant circulator to ensure water supply is available.

Energize the coolant-circulator switch.

2. Nitrogen-Oxygen Determinator. Change glass-wool dust trap at the end of each operative day.

Change copper oxide and the magnesium-perchlorate and Ascarite-filled tubes as needed (approximately every three weeks of normal operation).

Activate the digital-voltmeter switch.

Activate the auxiliary furnace switch.

Energize the two circuit breakers located on the rear of the determinator.

Activate the coolant-circulator power switch. The standby indicator should be green.

The helium-blanket indicator should be in the off position.

The furnace should be vacant and closed.

The oven indicator should be cycling on and off, and the oven temperature should be $\approx 45^{\circ} \mathrm{C}$.

The two helium regulators should be set for 40-psi pressure.

The measure-flow and the reference-flow rotometers should indicate the approximate helium-gas flow rate.

3. Instrument Start-Up.

Open the furnace by pulling the handle upward. The purge indicator will glow white, and the standby indicator will be off. The furnace must be cleaned thoroughly before each analysis.

Clean the upper electrode with a brush and cleansing tissue. 
Clean the lower electrode with a brush and cleansing tissue.

Do not contaminate the graphite crucible by touching with fingers.

Using tweezers, place crucible in the center of the lower electrode.

Depress the furnace handle to close the furnace. The purge indicator should then turn green.

The nitrogen-oxygen determinator is now ready for calibration with standard materials.

\section{Calibration of Nitrogen-Oxygen Determinator.}

(a) Determination of Nitrogen and Oxygen Crucible Blank.

With a graphite crucible in place, press the outgassing switch.

During outgassing, the furnace power indicator should indicate $600-800$ amperes.

After outgassing, the indicator turns green; turn the loading-head handle counter-clockwise $180^{\circ}$ to the down position. This simulates the drop of a blank or standard into the graphite crucible. Return the loading-head handle clockwise $180^{\circ}$ to the up position.

Press the analyze switch. The analyze indicator becomes white, and the outgassing indicator becomes inactive.

When the nitrogen and oxygen indicators glow green, the values of nitrogen and oxygen are shown on the respective digital voltmeter.

Open the furnace by raising the lower electrode handle; using tweezers, remove the crucible. Clean the furnace with a copper brush and cleansing tissue.

The crucible blank for nitrogen should read 0 or 1 on the digital voltmeter and 0 or 1 for oxygen.

(b) Calibration by Use of Leco Standards.

Open the sample-loading head by pulling the cylinder to the right, and place a Leco standard (or a control) sample in the sample cavity. Close the loading head by pushing the cylinder to the left.

Analyze the Leco standards as in Table 1. Readings on nitrogen and oxygen voltmeters must fall within the specitied limits. 
Proceed with each standard as in the "Determination of Nitrogen and Oxygen Crucible Blank". [see 4.(a) on Page 11 in this report].

If the standard values do not fall within the specified limits after two determinations of the $384-\mu \mathrm{g} / \mathrm{g}$-nitrogen and $68-\mu \mathrm{g} / \mathrm{g}$-oxygen standard, adjust to the correct values by using the nitrogen-slope and oxygen-slope potentiometers.

\begin{tabular}{|c|c|c|c|}
\hline LEC & $\begin{array}{l}\text { NITROG } \\
\text { TERMIN } \\
\text { A LEC }\end{array}$ & $\begin{array}{l}1 \\
\text { AND OXY } \\
\text { IONS WIT } \\
\text { TC30 }\end{array}$ & \\
\hline Leco S & dards & Lin & \\
\hline $\begin{array}{c}\text { Nitrogen } \\
\mu \mathrm{g} / \mathrm{g}\end{array}$ & $\begin{array}{c}\text { Oxygen } \\
\mu \mathrm{g} / \mathrm{g}\end{array}$ & $\begin{array}{c}\text { Nitrogen } \\
\mu \mathrm{g} / \mathrm{g}\end{array}$ & $\begin{array}{c}\text { Oxygen } \\
\mu g / g\end{array}$ \\
\hline 384 & 68 & \pm 14 & \pm 7 \\
\hline 109 & - & \pm 4 & - \\
\hline 44 & - & \pm 3 & - \\
\hline 11 & 50 & \pm 2 & \pm 3 \\
\hline
\end{tabular}

Repeat this procedure for the remaining standards. If the second standard is within limits, proceed to the next standard until all standards are within the prescribed limits.

\section{ANALYTICAL PROCEDURE}

\section{Sample Preparation}

Remove all surface scale and oxidation from the uranium-metal sample by abrading with a file. Do not subject the sample to excessive heat during preparation. Cut the sample into small pieces with a sample cutter. The uranium-metal sample aliquant should be less than a 1/4-inch cube.

Rinse the uranium-metal sample in acetone and air dry. Store the uranium-metal sample in a glass container. Weigh duplicate uranium-metal sample aliquants of $\approx 0.2$ grams each, and place in separate platinum cups. Fold the cup into a cube with $<1 / 4$-inch sides. Store in sample vials for analysis.

\section{Platinum Blank Analysis}

Place a platinum cup in the loading device of the furnace.

Repeat steps as outlined in the "Determination of Nitrogen and Oxygen Crucible Blank" [see 4.(a) on Page 11 of this report] .

Determine the platinum blank of $\approx 0.75$ gram of platinum foil shaped into a cylinder with one closed end (from a 1-inch square of 1-mil platinum foil which has been degreased with acetone and heated in a propane gas flame).

Subtract crucible blank reading from the gross reading for platinum blank reading. Typical platinum blank; nitrogen equals 2, oxygen equals 15 .

\section{Sample Analysis}

Place a prepared-sample aliquant in the loading device of the furnace. 
Repeat steps as shown in "Determination of Nitrogen and Oxygen Crucible Blànk" [see 4.(a) on Page 11 in this report].

Record digital-voltmeter readings and sample aliquant in grams.

\section{Preparation of Instrument for Standby}

Open furnace. Remove the crucible by using tweezers. Clean the furnace with a copper brush and cleansing tissues.

Clean upper electrode $O$ rings with cleansing tissue and regrease $O$ rings with silicone grease.

Close the furnace and push standby switch. The light will glow green, indicating the instrument is in standby. Allow helium flow to continue through the instrument.

Turn off the switch to the coolant circulator.

\section{Nitrogen and Oxygen Calculation}

Calculate the micrograms nitrogen per gram sample and the micrograms oxygen per gram sample in the unknown sample by using Equations 1 and 2.

$$
\begin{aligned}
& M_{N_{2}}=\frac{C_{N_{2}} \times F}{W} \\
& M_{O_{2}}=\frac{C_{O_{2}} \times F}{W}
\end{aligned}
$$

where:

$$
\begin{aligned}
& M_{N_{2}}=\text { the micrograms of nitrogen per gram of sample, } \\
& C_{N_{2}}=\text { the net nitrogen counts for the unknown sample, } \\
& F \quad \text { - lite iirstiument factor }-0.5 \text { with weight compensator on 0.5, } \\
& W \quad=\text { the weight of the sample in grams, } \\
& M_{\mathrm{O}_{2}}=\text { the micrograms of oxygen per gram of sample, and } \\
& C_{\mathrm{O}_{2}}=\text { the net oxygen counts for the unknown sample. }
\end{aligned}
$$




\section{RESULTS}

\section{Precision of Results}

A series of aliquants was analyzed to evaluate the precision of a method using a Leco standard at the $11-\mu \mathrm{g} / \mathrm{g}$-nitrogen level and 50- $\mu \mathrm{g} / \mathrm{g}$-oxygen level. At the $95 \%$-confidence level, the limit of error for a single determination is $\pm 2 \mu \mathrm{g} / \mathrm{g}$ for nitrogen at the $11-\mu \mathrm{g} / \mathrm{g}$-nitrogen level and $\pm 2 \mu \mathrm{g} / \mathrm{g}$ for oxygen at the $50-\mu \mathrm{g} / \mathrm{g}$-oxygen level.

The uranium metal was analyzed nine times for nitrogen and oxygen, resulting in a nitrogen value of $12 \mu \mathrm{g} / \mathrm{g}$ and an oxygen value of $20 \mu \mathrm{g} / \mathrm{g}$. The limit of error for a single determination at the $95 \%$-confidence level at the $12-\mu \mathrm{g} / \mathrm{g}$-nitrogen level is $\pm 3 \mu \mathrm{g} / \mathrm{g}$ nitrogen. The limit of error for a single determination at the $95 \%$-confidence level at the $20-\mu \mathrm{g} / \mathrm{g}$-oxygen level is $\pm 3 \mu \mathrm{g} / \mathrm{g}$ oxygen. 


\section{ACKNOWLEDGMENTS}

The author would like to thank H. G. King, Jr for his suggestions and comments during the preparation of this report. 


\section{Distribution}

Department of Energy - Oak Ridge

Hickman, H. D.

Leed, R. E.

Poteat, R. M.

Oak Ridge Gaseous Diffusion Plant

Armstrong, R. C.

Stief, S. S.

Wilcox, W. J., Jr

Oak Ridge $Y-12$ Plant

Andrew, R. E.

Bernander, N. K.

Briscoe, O. W.

Carden, W. F. (10)

Cole, S. H.

Dodson, W. H./Googin, J. M.

Dorsey, J. G.

Franklin, J. C.

Fraser, R. J.

Golson, T. J.

Keith, A.

Kent, R. H.

King, $H . G$., Jr

Kite, H. T. (20)

Mills, J. M., Jr

White, J. C.

$Y-12$ Central Files (master copy)

$Y-12$ Central Files (route copy)

$Y-12$ Central Files ( $Y-12 R C)$

$Y-12$ Central Files (5)

Paducah Gaseous Diffusion Plant

Bewley, H. D:

In addition, this report is distributed in accordance with the Category UC-4, Chemistry, as given in the Standard Distribution for Unclassified Scientific and Technical Reports, DOE/TIC-4500. 